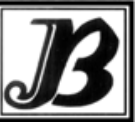

J. bio-sci. 17: 77-82, 2009

ISSN 1023-8654

http://www.banglajol.info/index.php/JBS/index

\title{
GENETIC VARIABILITY, DIVERSITY AND ASSOCIATION OF QUANTITATIVE TRAITS WITH GRAIN YIELD IN RICE (ORYZA SATIVAL.)
}

\author{
Praveen Pandey*, P John Anurag, D K Tiwari, S K Yadav, Binod Kumar \\ Department of Genetics and Plant Breeding, Allahabad Agricultural Institute-Deemed University, \\ Allahabad-211007 (U.P.) India
}

Abstract

Context: Genetic diversity is pre-requisite for any crop improvement programme as it helps in the development of superior recombinants.

\begin{abstract}
Objectives: Recognizing the importance of genetic diversity in plant breeding experiments, the present research work was taken up to estimate genetic diversity in different accessions of rice for various agroeconomically important characters.
\end{abstract}

\begin{abstract}
Materials and Methods: Experiments were carried out with 40 Rice (Oryza sativa L.) genotypes which were evaluated for yield and yield contributing traits in Kharif-2007-08. The data were recorded on 10 randomly selected plants from each replication for 12 quantitative characters studied. However days to $50 \%$ flowering was recorded on per plot basis. Mean values were subjected to analysis of variance to test the significance for each character. The genetic divergence was estimated and the grouping of the genotypes into cluster was done.
\end{abstract}

Results: Sufficient amount of variability was found in the entire gene pool for all traits studied. The higher magnitude of genotypic and phenotypic coefficients of variation was recorded for plant height, grain yield per hill, harvest index and biological yield per hill. High heritability along with high genetic advance as percent of mean was registered for harvest index, grain yield, plant height, biological yield, test weight, number of tillers per hill and number of spikelets per panicle suggesting preponderance of additive gene action in the expression of these characters. On the basis of Mahalanobis $D^{2}$ statistics the genotypes were grouped into seven clusters. Plant height, biological yield and test weight contributed considerably, accounting for $86.16 \%$ of total divergence. The genotypes superior in some clusters may be involve in a multiple crossing programme to recover transgressive segregants with high genetic yield potential and early maturity.

Conclusion: The promising genotypes selected from diverse clusters should be involved in the hybridization programme in order to transfer some of the desirable yield contributing characters consisted by them.

Key words: Rice (Oryza sativa), genetic variability, diversity, clustering pattern

\section{Introduction}

Genetic improvement of crop is largely depending on the magnitude of genetic variability and the extent to which desirable traits are heritable. Knowledge on the genetic architecture of genotypes is necessary to formulate efficient breeding methodology. Genetic variances serve as a basis for major plant breeding decision; they provide a greater array of genotypes among which selection can be practiced to develop still new varieties or breeding materials. Success in recombination breeding depends on the suitable exploitation

•Corresponding author:pandeypraveen1986@yahoo.com 
of genotypes as parents for obtaining high heterotic crosses and transgressive segregants. For this, the presence of sufficient amount of genetic variability and diversity in a base population is essential. There are only two effective ways to increase the yield potential of crops through plant breeding: morphological improvement and the use of heterosis. However, the potential is very limited when using morphological improvement alone and heterosis breeding will produce undesirable results if it is not combined with morphological improvement.

Elite rice hybrids have been found to possess disease and insect resistance and grain quality comparable with those of check varieties. Thus heterotic rice hybrids with the required resistance and grain quality can be developed by choosing appropriate parental lines. In any crop, the germplasm serves as a valuable source of base population and provides scope for wide variability. Information on the nature and degree of genetic divergence would help the plant breeder in choosing the right parents for breeding programme (Vivekanandan and Subramanian 1993). The crosses between parents with maximum genetic divergence are generally the most responsive for genetic improvement (Arunachalam 1981). This analysis provides a measurement of relative contribution of different components on diversity both at intra and inter-cluster level and genotypes drawn from widely divergent clusters are likely to produce hecterotic combinations and wide variability in segregating generation. The relative contribution of different yield components to total divergence using Mahalanobis D2-technique (Mahalanobis 1936) helps in the identification of selection parameter to be used as criteria for the improvement in the yield. Therefore, an attempt was made in the present studies to estimate the extent of variability, heritability, genetic advance and genetic divergence in rice genotypes.

\section{Materials and Methods}

The experimental material for the present study consisted of 40 rice genotypes were evaluated in RBD design in two replications at the Field Experimentation Centre of the Department of Genetics and Plant Breeding, Allahabad Agricultural Institute, Deemed University, Allahabad during Kharif, 2007-08. The data were recorded on 10 randomly selected plants from each replication for 12 quantitative characters studied were viz., plant height $(\mathrm{cm})$, number of panicles per hill, panicle length $(\mathrm{cm})$, flag leaf length $(\mathrm{cm})$, flag leaf width $(\mathrm{cm})$, number of spikelets per panicle, 1000 grain weight $(\mathrm{g})$, biological yield, grain yield per hill $(\mathrm{g})$, harvest index. However days to $50 \%$ flowering was recorded on per plot basis. Mean values were subjected to analysis of variance to test the significance for each character as per methodology advocated by Panse and Sukhatme (1967). Phenotypic coefficient of variation (PCV) and Genotypic coefficient of variation (GCV) were calculated by the formula given by Burton (1952), heritability in broad sense (h2) by Burton and De Vane (1953), and genetic advance i.e. the expected genetic gain were calculated by using the procedure proposed by Johnson et al (1955). The genetic divergence was estimated by Mahalanobis (1936) D2 statistics and the grouping of the genotypes into cluster were done by using Tocher's method (Rao 1952).

\section{Results and Discussion}

The analysis of variance revealed highly significant differences among the genotypes for the entire test characters, indicating the existence of variability among the varieties (Table 1). Considerable genetic divergence was also present among the genotypes. This suggested that adequate scope is available for selection of superior and diverse genotypes for use in a programmed aimed at enhancing genetic yield potential of rice. The estimates of PCV and GCV were high for plant height, number of tillers per hill, number of panicles per hill, grain yield, biological yield, harvest index, test weight, number of spikelets per panicle and flag leaf length whereas other characters showed relatively low variability (Table 1). However, there is still ample scope for selection of superior genotypes for these traits. 
The proportion of genetic variability which is transmitted from parents to offspring is reflected by heritability (Lush 1949). In the present study high heritability was observed for traits, plant height (99.8\%), biological yield per hill $(99.6 \%)$ ), harvest index (99.0\%), test weight (98.8\%), number of panicles per hill (98.5\%), number of spikelets per panicle (98.3\%), panicle length (97.7\%), number of tillers per hill (97.6\%), flag leaf length (97.2\%) and days to $50 \%$ flowering whereas flag leaf width (79.5\%) have moderate value (Table 1 ). Bhandarkar et al (2002) also recorded high heritability for plant height.

High heritability alone is not enough to make sufficient improvement though selection in advance generation where accompanied by substantial amount of genetic advance. Johnson et al. (1955) suggested that heritability and genetic advance when calculated together would prove more useful in predicting the resultant effect of selection on phenotypic expression. Based on this consideration high heritability coupled with high genetic advance as percent of mean was registered for harvest index (72.89), grain yield (55.27), plant height (49.51), biological yield (43.23), number of panicles per hill (40.28), number of tillers per hill (38.49), test weight (37.37) and number of spikelets per panicle (31.82) suggesting preponderance of additive gene action in the expression of these characters. Therefore, selection may be effective through these characters. High heritability associated with moderate genetic advance as percent of mean was observed for flag leaf length and panicle length. Whereas days to $50 \%$ flowering and flag leaf width recorded high heritability and low genetic advance as percent of mean which revealed the non- additive gene action in the expression of these characters in their inheritance, hence in this case selection may not be effective.

Based on relative magnitude of $D^{2}$ statistics the 40 genotypes of rice were grouped into 7 clusters (Table 2). Among the different clusters cluster VI consisted maximum number of genotypes (11genotypes) followed by cluster III (9 genotypes), cluster V (8 genotypes) and cluster I (4 genotypes), while cluster II and IV (each 3 genotypes) and cluster VII included 2 genotypes. The pattern of group constellation proved the existence of significant amount of variability. Similar findings also reported by Sarawgi and Bisne (2007). The clustering pattern of the genotypes revealed that the clustering did not follow any particular patterning with respect to the origin. The distribution of genotypes also indicated that the genotypes originated from different states were grouped into same clusters and genotypes of same states into different clusters. Therefore the kind of genetic diversity found among the genotypes belonging to same geographic origin might be due to differences in adaptation, selection criteria, selection pressure and environmental conditions (Maurya and Singh 1977).

The average intra cluster distance between the members of cluster-VII $(1805.04 \mathrm{~cm})$ was recorded highest followed by cluster III $(1206.70 \mathrm{~cm})$ and lowest for cluster-I $(532.62 \mathrm{~cm})($ Table 3). Maximum intra cluster distances in cluster VII indicating that genotypes in this cluster were relatively more diverse than the genotypes within other clusters. Hybridization programme involving genetically diverse parents belonging to different distant clusters would provide analysis opportunity for bringing together gene constellations of diverse nature, promising hybrid derivatives resulted probably due to complementary interaction of divergent genes in parents. The highest intercluster distance was observed between cluster II and VII (11235.93 cm), followed by II and VI $(8045.04 \mathrm{~cm})$ and I and VII $(7566.33 \mathrm{~cm})$ and lowest for IV and V $(1619.34 \mathrm{~cm})($ Table 3). The genotypes from cluster II (Triguna, MAUB-15, Pant dhan-6) having desired mean values for characters like days to $50 \%$ flowering, panicle length and harvest index, were more divergent from the genotypes of cluster VII (Sonachur and Mala) having desired mean value for plant height, flag leaf width, spikelets per panicle, biological yield and test weight, thus these genotypes may be used in hybridization programme to achieve desired segregants for early rice varieties with higher yield. 
Table 1. Estimation of mean, range, co-efficient of variation (PCV and GCV) heritability, genetic advance and genetic gain in 40 rice genotypes

\begin{tabular}{|c|c|c|c|c|c|c|c|c|}
\hline \multirow{2}{*}{ Characters } & \multirow[b]{2}{*}{ Mean } & \multicolumn{2}{|c|}{ Range } & \multirow[b]{2}{*}{ PCV } & \multicolumn{2}{|c|}{$h^{2}(\mathrm{bs})$} & \multirow{2}{*}{$\mathrm{GA}$} & \multirow{2}{*}{ GG } \\
\hline & & $\operatorname{Max}$ & Min & & GCV & $\%$ & & \\
\hline Days to $50 \%$ Flowering & 96.79 & 107.50 & 90.50 & 4.31 & 3.88 & 81.0 & 6.971 & 7.202 \\
\hline Plant height (cm) & 126.00 & 184.48 & 82.57 & 24.04 & 24.04 & 99.8 & 62.383 & 49.510 \\
\hline No. of Tillers/ hill & 13.03 & 18.65 & 7.55 & 19.14 & 18.91 & 97.6 & 5.017 & 38.497 \\
\hline Panicle Length (cm) & 24.25 & 28.58 & 16.30 & 9.97 & 9.86 & 97.7 & 4.866 & 20.065 \\
\hline No. of Panicles/ hill & 12.37 & 18.10 & 7.35 & 19.86 & 19.71 & 98.5 & 4.984 & 40.283 \\
\hline Flag Leaf Length $(\mathrm{cm})$ & 33.81 & 42.85 & 26.38 & 11.97 & 11.81 & 97.2 & 8.109 & 23.981 \\
\hline Flag Leaf width (cm) & 1.58 & 3.81 & 1.28 & 8.42 & 7.50 & 79.5 & 0.218 & 13.778 \\
\hline No. of Spikelets/ Panicle & 188.91 & 247.40 & 136.25 & 15.72 & 15.58 & 98.3 & 60.113 & 31.820 \\
\hline Biological Yield (g) & 83.33 & 125.20 & 45.50 & 21.07 & 21.03 & 99.6 & 36.027 & 43.236 \\
\hline Grain Yield (g) & 21.02 & 33.10 & 9.80 & 27.36 & 27.09 & 98.1 & 11.622 & 55.277 \\
\hline Harvest Index (\%) & 26.38 & 48.92 & 13.79 & 35.73 & 35.56 & 99.0 & 19.226 & 72.891 \\
\hline Test Weight (g) & 18.01 & 25.93 & 12.60 & 18.37 & 18.25 & 98.8 & 7.031 & 37.372 \\
\hline
\end{tabular}

Table 2. Distribution of 40 genotypes of Rice into different clusters

\begin{tabular}{clc}
\hline $\begin{array}{c}\text { Cluster } \\
\text { No. }\end{array}$ & Name of genotypes included & $\begin{array}{c}\text { Number of } \\
\text { genotypes }\end{array}$ \\
\hline I & Narendra-359, Sarjo0-52, Pusa-44, Indrani & 4 \\
II & Triguna, MAUB-15, Pant dhan-6 & 3 \\
III & $\begin{array}{l}\text { OR-7141, Rasi, China, IET-15833-02, HKR-20-436, HUR-3022, Sambha mahsuri, } \\
\text { Dudagi, NDR-2070 }\end{array}$ & 9 \\
IV & Pusa basmati-1, NDR-6117, Pant dhan-4 & 3 \\
V & $\begin{array}{l}\text { Chinikamini,Chaita-4, Judi-578, Mahsuri, Golden,UPR-2581-21-1-2, CRAC-2221- } \\
\text { LI,HUBR-02-01 }\end{array}$ & 8 \\
VI & $\begin{array}{l}\text { Bayalu, Bhata Swarna, Jhumeri, Ranikajal, Tulsimuni, Chullai, Lohandi, Bala, } \\
\text { IET-15358, Vishnubhog, Dubraj }\end{array}$ & 11 \\
& Sonachur, Mala & 2 \\
\hline
\end{tabular}

Table 3. Intra (diagonal) and inter cluster average distance ( $\left.D^{2}\right)$ in Rice genotypes.

\begin{tabular}{cccccccc}
\hline Cluster & I & II & III & IV & V & VI & VII \\
\hline I & 532.62 & 1631.56 & 2144.58 & 1729.60 & 2467.70 & 6052.86 & 7566.33 \\
II & & 845.28 & 2536.50 & 2983.64 & 4471.74 & 8045.04 & 11235.93 \\
III & & & 1206.70 & 2274.50 & 1996.88 & 3513.58 & 5821.70 \\
IV & & & & 986.54 & 1619.34 & 5018.56 & 6348.25 \\
V & & & & & 722.58 & 3045.92 & 3511.75 \\
VI & & & & & & 896.09 & 2040.87 \\
VII & & & & & & & 1805.04 \\
\hline
\end{tabular}


Table 4. Percent contribution of each character towards genetic divergence in 40 Rice genotypes.

\begin{tabular}{lcc}
\hline Characters & Times Ranked 1st & Contribution \% \\
\hline Days to 50\% Flowering & 0 & 0 \\
Plant Height & 373 & 47.82 \\
Tillers/ Hill & 5 & 0.64 \\
Panicle Length & 13 & 1.67 \\
Panicles/ Hill & 33 & 4.23 \\
Flag Leaf Length & 11 & 1.41 \\
Flag Leaf width & 0 & 0.00 \\
Spikelets/ Panicle & 20 & 2.56 \\
Biological Yield & 235 & 30.13 \\
Grain Yield & 13 & 1.67 \\
Harvest Index\% & 13 & 1.67 \\
Test Weight (1000 seed) & 64 & 8.21 \\
\hline
\end{tabular}

Table 5. Mean values of seven clusters for 12 quntitative characters in 40 Rice genotypes

\begin{tabular}{cccccccccccc}
\hline Cluster & $\begin{array}{c}\text { Days to } \\
50 \% \\
\text { Flowering }\end{array}$ & $\begin{array}{c}\text { Plant } \\
\text { Height } \\
(\mathrm{cm})\end{array}$ & Tillers/ Hill & $\begin{array}{c}\text { Panicle } \\
\text { Length } \\
(\mathrm{cm})\end{array}$ & $\begin{array}{c}\text { Flag Leaf } \\
\text { Length } \\
(\mathrm{cm})\end{array}$ & $\begin{array}{c}\text { Flag Leaf } \\
\text { width }(\mathrm{cm})\end{array}$ & $\begin{array}{c}\text { Spikelet/ } \\
\text { Panicle }\end{array}$ & $\begin{array}{c}\text { Biological } \\
\text { Yield } \\
(\mathrm{g})\end{array}$ & $\begin{array}{c}\text { Grain Yield } \\
(\mathrm{g})\end{array}$ & $\begin{array}{c}\text { Harvest } \\
\text { Index } \\
\%\end{array}$ & $\begin{array}{c}\text { Test } \\
\text { Weight (g) }\end{array}$ \\
\hline I & 95.25 & 97.82 & 10.09 & 25.65 & 33.04 & 1.47 & 142.08 & 69.55 & 27.48 & 39.33 & 24.41 \\
II & 93.50 & 87.72 & 9.25 & 24.89 & 32.19 & 1.45 & 173.60 & 54.71 & 24.58 & 45.12 & 17.64 \\
III & 96.00 & 115.34 & 13.61 & 22.34 & 34.45 & 1.55 & 182.48 & 70.38 & 17.14 & 24.84 & 17.41 \\
IV & 94.50 & 95.89 & 13.06 & 24.87 & 28.89 & 1.46 & 159.38 & 88.52 & 28.08 & 32.33 & 16.09 \\
V & 98.50 & 113.95 & 12.61 & 25.68 & 35.20 & 1.61 & 205.72 & 101.30 & 23.39 & 23.23 & 19.33 \\
VI & 98.22 & 165.08 & 14.90 & 24.18 & 34.53 & 1.66 & 202.97 & 86.52 & 16.84 & 19.68 & 17.57 \\
VII & 97.00 & 166.08 & 13.30 & 22.85 & 32.77 & 1.71 & 234.25 & 114.77 & 23.17 & 19.67 & 24.49 \\
\hline
\end{tabular}

The selection and choice of parents mainly depends upon contribution of characters towards divergence. Highest contribution in manifestation of genetic divergence was exhibited by plant height (47.82\%) followed by biological yield (30.13\%), test weight (8.21\%) and spikelets per panicle (2.56\%) (Table 5). Usha-Kumari and Rangasamy (1997) also reported that the characters grain yield per hill and plant height have contributed maximum to divergence and should from the basis of selection for genotypes. Tillers per hill $(0.64 \%)$, flag leaf length (1.41\%), Panicle length, grain yield (1.67\%) and harvest index (1.67\%) contributed least among all the characters towards genetic divergence (Table 4). Nayak et al. (2004) also reported that the minimum contribution of panicle length among all the characters. Whereas Naik et al (2006) reported the maximum contribution of grain yield per hill towards genetic divergence.

Based on cluster means (Table 5), they have been identified for selecting parents for future hybridization programme and accordingly, cluster II has been identified for selecting parents for incorporating early maturity, Cluster IV for grain yield, Cluster VI for Tillers per hill Cluster VII for Plant height, flag leaf width, number of spikelets per panicle, biological yield and test weight and Cluster $\vee$ for Panicle length, panicles per hill and flag leaf length. The genotypes superior in the above cluster may be involve in a multiple crossing programme to recover transgressive segregants with high genetic yield potential and early maturity.

\section{Conclusion}

The studied characters may serve as an effective selection parameter during breeding programme for rice crop improvement. The promising genotypes selected from diverse clusters should be involved in the hybridization programme in order to transfer some of the desirable yield contributing characters consisted by them. 


\section{References}

Arunachalam V. 1981. Genetic divergence in plant breeding. Indian J Genet 14, 226-236.

Bhandarkar S, Verma R, Kumar A. 2002. Genetic variability and correlation analysis in early duration rice. Plant Archives 2 (1), 95-98.

Burton GW. 1952. Quantitative inheritance of grasses. Proc 6th Int, Grassland Congress 1, 277-283.

Burton GW, De Vane EH. 1953. Estimating heritability in tall fescue (Festuca arundinacea) from replicated clonal material. Agronomy J 45, 478-481. doi:10.2134/agronj1953.00021962004500100005x

Johnson HW, Robinson HF, Comstock RE. 1955. Estimates of genetic and environmental variability in soybeans. Agronomy J 47, 314-318. doi:10.2134/agronj1955.00021962004700070009x

Lush JL. 1949. Heritability of quantitative characters in farm animals. Hereditas (suppl), 356-375.

Mahalanobis PC. 1936. On the generalized distance in statistics. Proc Natl Inst Sci India 2, 49-55.

Maurya DM, Singh DP. 1977. Genetic divergence in rice. Indian J Genet 37(3), 395-402.

Naik D, Sao A, Sarawgi AK, Singh P. 2006. Genetic divergence studies in scented rice. J PI Sci 5(2), 197-200.

Nayak AR, Chaudhury D, Reddy JN. 2004. Genetic divergence in scented rice. Oryza 41(384), 79-82.

Panse VG, Sukhatme PV. 1967. Statistical methods for agricultural workers $2^{\text {nd }}$ edn:, ICAR, New Delhi, 381pp.

Rao CR. 1952. Advance Statistical Methods in Brometrical Research. John Wiley and Sons, Increased. New York.

Sarawgi AK, Bisne R. 2007. Studies on genetic divergence of aromatic rice germplasm for agromorphological and quality characters. Oryza 44 (1), 74-76.

Usha-Kumary RU, Rangasamy P. 1997. Studies on genetic diversity in early rice genotypes. Annu Agric Res 18 (1) 29-33.

Vivekanandan P, Subramanian S. 1993. Genetic divergence in rainfed rice. Oryza 30, 60-62. 